\title{
Kinetics and Mechanism of Thermal Decomposition of 1-R-Substituted bis(1,1-Dinitromethyl-3-Nitro-
}

\section{1,2,4-Triazole-5-yl)}

\author{
Lyudmila A. Kruglyakova, Rudolf S. Stepanov, \\ Konstantin V. Pekhotin and Oksana A. Golubtsova* \\ Reshetnev Siberian State University \\ of Science and Technology \\ Krasnoyarsk, Russian Federation
}

Received 15.05.2019, received in revised form 01.07.2019, accepted 10.10.2019

Abstract. Thermal decomposition kinetics of 1-substituted bis(1,1-dinitromethyl-3-Nitro-1,2,4-triazole5 -yl) in solution of 1,3-dinitrobenzene is studied with manometric method under isothermal conditions. The limiting stage of thermal decomposition is homolytic break of C-NO $\mathrm{N}_{2}$ bond in gem-dinitromethyl group; activation parameters of this stage are calculated. The reactivity of investigated compounds is analyzed. Correlation dependences between logarithm of rate constant, activation energy and steric constant of substituent $\mathrm{R}$ are obtained.

Keywords: kinetics, thermal decomposition, bis(1-R-1,1-dinitromethyl-3-nitro-1,2,4-triazole-5-yl), activation parameters, steric constants, correlation.

Citation: Kruglyakova L.A., Stepanov R.S., Pekhotin K.V., Golubtsova O.A. Kinetics and mechanism of thermal decomposition of 1-R-substituted bis(1,1-dinitromethyl-3-Nitro-1,2,4-triazole-5-yl), J. Sib. Fed. Univ. Chem., 2020, 13(1), 25 30. DOI: $10.17516 / 1998-2836-0157$

(C) Siberian Federal University. All rights reserved

This work is licensed under a Creative Commons Attribution-NonCommercial 4.0 International License (CC BY-NC 4.0).

* Corresponding author E-mail address: lakruglyakova@sibsau.ru 


\title{
Кинетика и механизм термического разложения
}

\section{1-R-замещенного бис(1,1-динитрометил-3-нитро-}

\section{1,2,4-триазол-5-ила)}

\author{
Л.А. Круглякова, Р.С. Степанов, \\ К.В. Пехотин, О.А. Голубцова \\ Сибирский государственный университет науки \\ и технологий им. академика М.Ф. Решетнева \\ Российская Федераџия, Красноярск
}

Аннотация. Манометрическим методом в изотермических условиях изучена кинетика термического разложения 1-R-замещенных бис(1,1-динитрометил-3-нитро-1,2,4-триазол-5-ила) в растворе 1,3-динитробензола. Определена лимитирующая стадия распада - гомолитический разрыв связи $\mathrm{C}-\mathrm{NO}_{2}$ в гем-динитрометильной группе, для которой найдены активационные параметры. Проведен анализ реакционной способности изученных соединений и получены корреляционные зависимости между логарифмом константы скорости, энергией активации и стерической константой заместителя R.

Ключевые слова: кинетика, термическое разложение, бис(1-R-1,1-динитрометил-3-нитро-1,2,4триазол-5-ил), активационные параметры, стерические константы, корреляция.

Цитирование: Круглякова, Л.А. Кинетика и механизм термического разложения 1-R-замещенного бис(1,1динитрометил-3-нитро-1,2,4-триазол-5-ила) / Л.А. Круглякова, Р.С. Степанов, К.В. Пехотин, О.А. Голубцова // Журн. Сиб. федер. ун-та. Химия, 2020. 13(1). С. 25-30. DOI: 10.17516/1998-2836-0157

\section{Introduction}

In recent years polynitrocompounds on the basis of 1,2,3- and 1,2,4-triazoles, 1,2,3,4-tetrazoles are the subject of numerous studies [1-5] because they are of interest as explosives and components of gunpowders and rocket fuel [3-5]. The practical use of these substances requires knowledge of a complex of properties including thermal stability. Thermal decomposition of nitro derivatives of azoles described in works [6-8], in which the mechanism of decomposition and the dependence between structure and reactivity are established. At the same time, information about the thermal stability of compounds with two triazole cycles in the literature are very limited.

In continuation of the works [6-8] on the influence of substituent nature on the azole's decomposition rate we for the first time investigated derivatives of bis(1-R-1,1-dinitromethyl-3-nitro1,2,4-triazole-5-yl)<smiles>[R]OC(=O)n1nc([N+](=O)[O-])nc1-c1nc([N+](=O)[O-])nn1C([R])O[Na]</smiles> 
where $\mathrm{R}=\mathrm{CH}_{3}(\mathrm{I}), \mathrm{CH}_{2} \mathrm{~N}\left(\mathrm{NO}_{2}\right) \mathrm{CH}_{3}(\mathrm{II}), \mathrm{CH}_{2} \mathrm{CN}$ (III), $\mathrm{NO}_{2}(\mathrm{IV}), \mathrm{Cl}(\mathrm{V}), \mathrm{Br}(\mathrm{VI}), \mathrm{I}(\mathrm{VII})$.

\section{Experimental Part}

Compounds (I-VII) were synthesized and purified by known methods [5, 9], were chromatographically pure and contained not less than $99.5 \%$ basic substance.

Thermal decomposition kinetics was studied by manometric method in vacuum using a glass manometer of Bourdon type [6] as well as by photoelectrocolorimetric method on accumulation of nitrogen dioxide [10] during decomposition.

Thermal decomposition rate constants were calculated by the Guggenheim method [11]. The rate constants definition error did not exceed 7\%. An r.m.s. deviation for calculation of activation energy was $4,3 \mathrm{~kJ} \cdot \mathrm{mol}^{-1}$, and for logarithm of pre-exponential factor 0.11 unit of logarithm.

\section{Experimental Results and Discussion}

The study showed that the thermal decomposition of compounds (I-VII) in a solution of 1,3-dinitrobenzene (DNB) described by the equation of first order reaction up to the transformation degree $45-50 \%$. Decomposition rate constants are not affected by the concentration of a substance in a solution within $1-5 \%$ (mass). With this in mind, the effect of temperature on the rate constant was studied in $2-2,5 \%$ solutions.

Kinetic and thermodynamic parameters of thermal decomposition are shown in Table. Here also substituent's steric constants $E_{\mathrm{s}}$ are presented, taken from the work of [12].

Analysis of the data in the table shows that with increasing of absolute value of steric constants $E_{\mathrm{s}}$ of substituents $\mathrm{R}$ in gem-dinitromethyl group the decomposition rate constants reduced for three orders of magnitude. At the same time decrease in value of activation energy from 160,5 to $135,3 \mathrm{~kJ} \cdot \mathrm{mol}^{-1}$ take place, at practically constant logarithm of pre-exponential factor, equal, on average, 15,66 unit of logarithm. The entropies of activation for investigated compounds (I-VII) are positive.

Similar regularities were observed earlier in thermal decomposition of 1-substituted 3-nitro1,1-dinitromethyl-1,2,4-triazole, 1,1-dinitromethyl-2-methyl-1,2,3-triazole derivatives, and

Table. Thermal decomposition activation parameters, steric constants of substituents and activation entropies of compounds (I-VII) in 2-2,5\% solutions of dinitrobenzene

\begin{tabular}{|c|c|c|c|c|c|c|c|}
\hline № & Substituent R & $\Delta T,{ }^{\circ} \mathrm{C}$ & $E_{\mathrm{a}}, \mathrm{kJ} \cdot \mathrm{mol}^{-1}$ & $\lg A$ & $k_{160^{\circ} \mathrm{C}}, \mathrm{s}^{-1}$ & $\Delta S^{\neq}{ }_{160^{\circ} \mathrm{C}}, \mathrm{kJ} \cdot \mathrm{mol}^{-1} \cdot \mathrm{K}^{-1}$ & $E_{\mathrm{s}}$ \\
\hline I & $\mathrm{CH}_{3}$ & $140-180$ & 160,5 & 15,94 & $3,81 \cdot 10^{-4}$ & 48,7 & 0 \\
\hline II & $\mathrm{CH}_{2} \mathrm{~N}\left(\mathrm{NO}_{2}\right) \mathrm{CH}_{3}$ & $140-180$ & 157,3 & 15,89 & $8,26 \cdot 10^{-4}$ & 47,8 & $-0,58$ \\
\hline III & $\mathrm{CH}_{2} \mathrm{CN}$ & $140-180$ & 154,2 & 15,55 & $8,93 \cdot 10^{-4}$ & 41,3 & $-0,76$ \\
\hline IV & $\begin{array}{l}\mathrm{NO}_{2} \\
\mathrm{NO}_{2} *\end{array}$ & $\begin{array}{l}120-160 \\
120-140\end{array}$ & $\begin{array}{l}146,5 \\
148,3\end{array}$ & $\begin{array}{l}15,72 \\
15,88\end{array}$ & $\begin{array}{l}1,12 \cdot 10^{-2} \\
9,83 \cdot 10^{-3}\end{array}$ & $\begin{array}{l}44,5 \\
47,6\end{array}$ & $-2,14$ \\
\hline V & $\mathrm{Cl}$ & $110-150$ & 141,0 & 15,55 & $3,49 \cdot 10^{-2}$ & 41,3 & $-2,81$ \\
\hline VI & $\mathrm{Br}$ & $110-140$ & 136,1 & 15,49 & $1,18 \cdot 10^{-1}$ & 40,1 & $-3,44$ \\
\hline VII & I & $100-140$ & 135,3 & 15,48 & $1,45 \cdot 10^{-1}$ & 39,9 & $-3,62$ \\
\hline
\end{tabular}

Note: $*$ - on accumulation of $\mathrm{NO}_{2}$. 
5-dinitromethyl-2-methyl-1,2,3,4-tetrazole [6-8], which limiting thermal decomposition stage includes a homolytic reaction breaking of $\mathrm{C}-\mathrm{NO}_{2}$ bond in geminal dinitromethyl fragment. Obviously, the same mechanism is implemented in thermal decomposition of studied compounds (I-VII). Proof of this are the data obtained during the study of the thermal decomposition kinetics of compound (IV) using photoelectrocolorimetric method for accumulation of nitrogen dioxide. Nitrogen dioxide is a primary product formed during the decomposition. As can be seen from the table, the activation parameters for the compound (IV) found on the accumulation of nitrogen dioxide, are close to that of manometric measurements (the difference does not exceed definition error).

In addition, quantitative description of the reactivity of the studied compounds depending on the nature of substituent also accords well with this mechanism. So, it follows from Fig. 1-2, that thermal decomposition rate constants of substituted bis(1-R-1,1-dinitromethyl-3-nitro-1,2,4-triazole-5-yl), as well as activation energies correlate well with steric constants of substituents.

Found dependencies can be described by regression equations:

$$
\begin{aligned}
& \lg k_{160^{\circ} \mathrm{C}}=-(0,737 \pm 0,017) E_{\mathrm{s}}-(3,509 \pm 0,039), \\
& \mathrm{r}=0,998 ; \mathrm{S}_{\mathrm{y}}=0,145 ; \mathrm{n}=7, \\
& E_{\mathrm{a}}=(6,99 \pm 0,19) E_{\mathrm{s}}+(160,60 \pm 0,44), \\
& \mathrm{r}=0,997 ; \mathrm{S}_{\mathrm{y}}=1,65 ; \mathrm{n}=7 .
\end{aligned}
$$

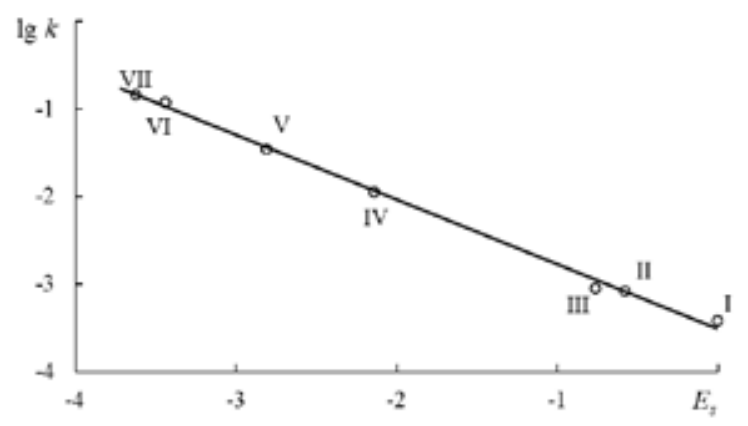

Fig. 1. Dependence $\lg k_{160^{\circ} \mathrm{C}}=\mathrm{f}\left(E_{\mathrm{s}}\right)$

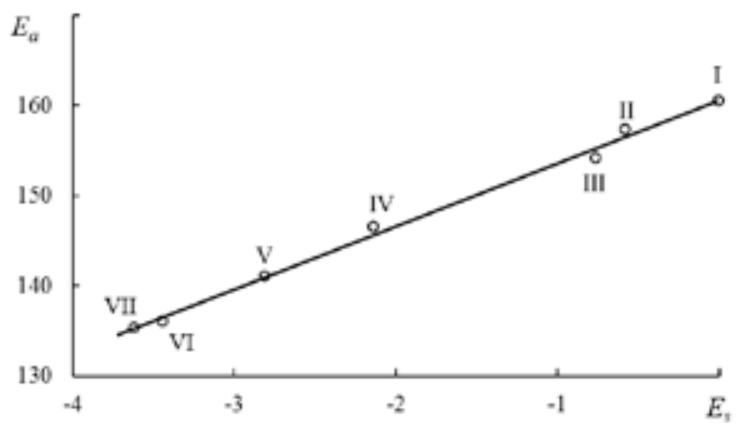

Fig. 2. Dependence $E_{\mathrm{a}}=\mathrm{f}\left(E_{\mathrm{s}}\right)$ 
Equations (1) and (2) can be used for purposeful synthesis of bicyclic derivatives of 1,1-dinitromethyl-1,2,4-triazole with preset parameters on chemical stability.

\section{Conclusion}

Thermal decomposition of 1-substituted bis(1,1-dinitromethyl-3-nitro-1,2,4-triazole-5-yl) in a solution of 1,3-dinitrobenzene flows through first-order reactions with primary break of $\mathrm{C}-\mathrm{NO}_{2}$ bond in geminal dinitromethyl fragment. The activation parameters are found for limiting stage. The correlation dependences between the logarithm of the rate constants, activation energies and substituent's steric constants are obtained, allowing for a preliminary assessment of the thermal stability of the unexplored compounds of this row.

\section{References / Список литературы}

1. Gobel M., Klapotke T.M. Development and Testing of Energetic Materials: the Concept of High Densities Based on the Trinitroethyl Functionality. Adv. Funct. Mater. 2009. Vol. 19(3), P. 347365 .

2. Thottempudi V., Gao H.X., Shreeve J.M. Trinitromethyl-substituted 5-Nitro- or 3-Azo-1,2,4triazoles: Synthesis, Characterization, and Energetic Properties. J. Am. Chem. Soc. 2011. Vol. 133(16), P. 6464-6471.

3. Klapötke T.M., Sabate C.M. Bistetrazoles: Nitrogen-rich, High-performing, Insensitive Energetic Compounds. Chem. Mater. 2008. Vol. 20(11), P. 3629-3637.

4. Thottempudi V., Gao H.X., Shreeve J.M., Synthesis and Promising Properties of a New Family of High-density Energetic Salts of 5-Nitro-3-trinitromethyl-1H-1,2,4-triazole and 5,5'-Bis(trinitromethyl)3,3'-azo-1H-1,2,4-triazole. J. Am. Chem. Soc. 2011. Vol. 133(49), P. 19982-19992.

5. Певзнер М.С. Производные 1,2,4-триазола. Рос. хим. журн. 1997. Т. 41(2), С. 73-83. [Pevzner M.S. Derivatives of 1, 2, 4-triazole. Ross. Khim. Zhurn. (Zhurn. Ross. Khim. ob-va im. D.I. Mendeleeva) [Mendeleev Chem. J.]. 1997. Vol. 41(2), P. 73-83 (In Russ.)]

6. Степанов Р.С., Круглякова Л.А., Астахов А.М. Термораспад производных 3-нитро-1,1динитрометил-1,2,4-триазола в растворе. Журнал органической химии. 2007. Т. 43 (3), С. 473. [Stepanov R.S., Kruglyakova L.A., Astakhov A.M. Thermal decomposition of 1-dinitromethyl-3nitro-1,2,4-triazole derivatives in solution. Russ. J. Org. Chem. 2007. Vol. 43(3). P. 474.]

7. Stepanov R.S., Kruglyakova L.A., Astachov A.M. Thermal decomposition kinetics and mechanism of 5-gem-dinitromethyl substituted 2-methyl-1,2,3-triazoles. Energetic Materials: Characterisation and Performance of Advanced Systems. 38 ${ }^{\text {th }}$ International ICT-Conference. 2007. Karlsruhe. FRG, P. 62/1-62/8.

8. Степанов Р.С., Астахов А.М., Круглякова Л.А., Голубцова О.А. Кинетика и механизм термического разложения некоторых производных 5-динитрометил-2-метилтетразола. Журнал общей химии 2000. T. 70(6), C. 999-1001. [Stepanov R.S., Astachov A.M., Kruglyakova L.A., Golubtsova O.A. Kinetics and mechanism of thermal decomposition of 5-dinitromethyl-2methyltetrazole derivatives. Russ. J. of Gen. Chem. 2000. Vol. 70(6). P. 934-936.]

9. Семенов В.В., Шевелев С.А., Брускин А.Б., Канищев М.И., Барышников А.Т. Механизм нитрования $\mathrm{N}$-ацетонильных производных азтсодержащих гетероциклов. Общий подход к синтезу N-динитрометилазолов. Известия АН. Сер. хим. 2009. № 10, С. 2014-2023. 
[Semenov V.V., Shevelev S.A., Bruskin A.B., Kanishchev M.I., Baryshnikov A.T. Mechanism ofnitration ofnitrogen-containingheterocyclic N-acetonyl derivatives. Generalapproach to the synthesisof N-dinitromethylazoles. Russ. Chem. Bull. 2009. No. 10. P. 2077-2096.]

10. Булатов М.И., Калинкин И.К. Практическое руководство по фотоколори-метрическим методам анализа. Л.: Химия, 1972. 408 с. [Bulatov M.I., Kalinkin I.K. A practical guide to photo colorimetric methods of analysis. Leningrad, Chemistry, 1972. 408 p. (In Russ.)]

11. Guggenheim E.A., Prue J.E. Physicochemical calculations. Amsterdam: North-Holland Publishing Company, 1956. $491 \mathrm{p}$.

12. Шанько В.Н., Степанов Р.С., Гидаспов Б.В. О применении корреляционных уравнений к реакции термического разложения полинитроалканов. Материалы конф. по итогам научно-исслед. работ. Секиия органической химии. Красноярск: Изд-во СТИ, 1971. С. 41-45. [Shan'ko V.N., Stepanov R.S., Gidaspov B.V. On the application of correlation equations for reaction thermal decomposition of polynitroalkanes. Materials of conference over scientific-investigation results. Organic Chemistry section. Krasnoyarsk, STI. 1971. P. 41-45. (In Russ.)] 